\title{
The XY Gonadal Agenesis Syndrome
}

\author{
GLORIA E. SARTO and JOHN M. OPITZ \\ Departments of Gynecology and Obstetrics, Pediatrics and Medical Genetics, University of Wisconsin Center for \\ Health Sciences and Medical School, Madison, Wisconsin, USA
}

\begin{abstract}
Summary. A patient with a $46, \mathrm{XY}$ chromosome constitution showed the following main characteristics: eunuchoidal body habitus, lack of secondary sexual development, normal female external genitalia with absence of vagina, no gonadal structures, and complete lack of internal genitalia except for rudimentary ductal structures defined by histological examination. Her condition is clearly different from that of feminizing testis syndrome and Swyer syndrome individuals. We would like to include her and six similar patients from the literature in a newly defined 'XY gonadal agenesis' syndrome.
\end{abstract}

In mammals, the male sex determining 'factor(s)' is located on the $\mathrm{Y}$ chromosome. Though the presence of a $\mathrm{Y}$ chromosome is able to overcome the effects of more than one $\mathrm{X}$ chromosome in determining the male sex, a number of genes, not on the $Y$ chromosome, are able to disturb this role. The best known examples of this phenomenon are the feminizing testis syndrome (FTS) and the Swyer syndrome, in which non-mosaic $46, \mathrm{XY}$ individuals have a female phenotype. The present paper describes another condition, 'the gonadal agenesis syndrome' characterized by a $46, \mathrm{XY}$ sex chromosome constitution and a female phenotype. The present case is compared to similar ones found in the literature.

\section{Case Report}

MS012344 was first seen elsewhere at the age of 16 years for primary amenorrhoea and intermittent abdominal pain. Examination then (in 1960) showed a rather stocky habitus, no axillary and scant pubic hair, no breast development, a normal clitoris, immature labia majora and minora, and absence of the vagina; uterus and gonads could not be palpated. Breast development occurred only after oestrogen therapy. Cyclically recurrent abdominal pain led to hospitalization in 1961, when she was found to excrete normal amounts of 17 -ketosteroids and to be $\mathrm{X}$-chromatin nega-

Received 18 December 1972.

Research aided in part by NIH grants Nos. HD 03084-03, GM 08217, GM 15422, 5 KO 4 HD 18982 (Career Development Award J.M.O.), and by grants from the National Foundation-March of Dimes, and Racine Health Fund. tive. Intravenous pyelography disclosed no abnormalities of kidneys, ureters, or bladder. At exploratory laparotomy, no internal genitalia or gonads were found. At the left pelvic wall was a small mass of tissue (measuring $1.0 \times 0.5 \mathrm{~cm}$ ) to which was attached a rudimentary fallopian tube. Similar, but smaller structures were present on the right; microscopic examination of these confirmed the diagnosis of a rudimentary fallopian tube.

The patient was first seen at the University of Wisconsin Hospitals in 1964. The history of primary amenorrhoea and failure of breast development until after exogenous oestrogen treatment, was confirmed.

She was born after an uneventful pregnancy of normal duration, weighing $3062 \mathrm{~g}$ and measuring $46 \mathrm{~cm}$ in length. Her health during childhood and adolescence was good, and she was of normal intelligence. Her height was around the third centile (for girls) until treatment with sex steroids at the age of 16 years. During the period of hormonal therapy she claims to have increased in height from 150 (fifth centile for girls) to $160 \mathrm{~cm}(>10<25$ th centile for girls).

\section{Family History}

This is essentially unremarkable. She was the first of her mother's seven pregnancies which resulted in the birth of three sisters (now 20,17, and 8 years old) and two brothers (13 and 11 years old). The seventh pregnancy resulted in a spontaneous abortion. All girls are of normal height. They matured at the usual age for their sex; they are of normal intelligence and have no anomalies like those of the patient. The 20-year-old sister is married and has one child; the 17-year-old sister is menstruating normally. Mother and father were 30 and 31 years old respectively when the patient 
was born; they are apparently not related to each other and they are of normal intelligence and stature (161.5 and $175.5 \mathrm{~cm}$, respectively). No relative is known to have had problems like those of the patient.

FIG. 1
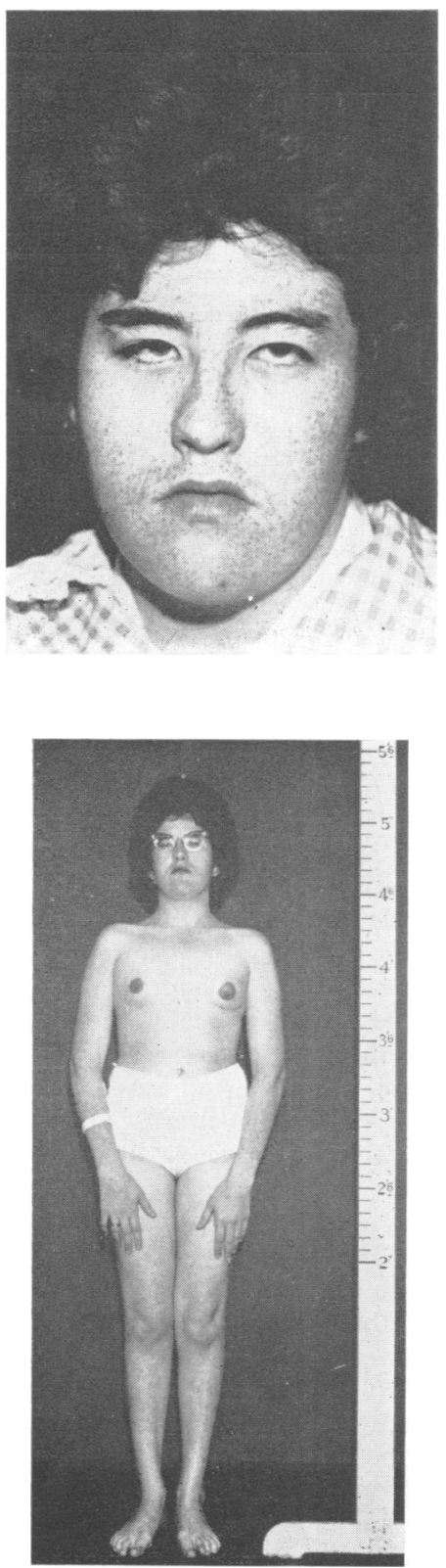

FIG. 2

FIGS. 1 and 2. Face and general appearance of the patient; age 21 years.

\section{Physical Examination of the Proposita}

At the age of 21 years (Figs. 1 and 2) her height was $160 \mathrm{~cm}$ and she weighed $52 \cdot 16 \mathrm{~g}$. She had slightly eunuchoidal body proportions. In addition to the genital malformations, she manifested several minor anomalies including a rather low posterior scalpline, a high, arched palate, bilateral ptosis with true mongolian upper lids, slightly oblong corneae with a suggestion of heterochromia iridis (right iris brown, left greenish-grey), nystagmus, a distal axial palmar triradius $(50 \%)$ on the right with a relatively low* finger tip total dermatoglyphic ridge count (nine ulnar loops and one radial loop with a total ridge count of 112). Her skin was dry and the subcutaneous veins were prominently visible. The scalp hair was unusually coarse and there was hirsutism of arms and legs. Her face was covered with innumerable small freckles. She did not show shortness of metacarpals or metatarsals, nail defects, webbing of the neck, cubitus valgus, or signs of congenital heart disease. The rest of the physical examination was unremarkable.

\section{Cytogenetic Studies}

Feulgen stained buccal mucosal cells did not show any $\mathrm{X}$-chromatin bodies. Analysis of 33 lymphocytes and of 10 fibroblasts revealed a 46,XY chromosome constitution. The $\mathrm{Y}$ chromosome showed a typical appearance and characteristic fluorescence pattern (Fig. 3). It was fairly large, and agreed in size with the $\mathrm{Y}$ chromosome of the father and her two brothers.

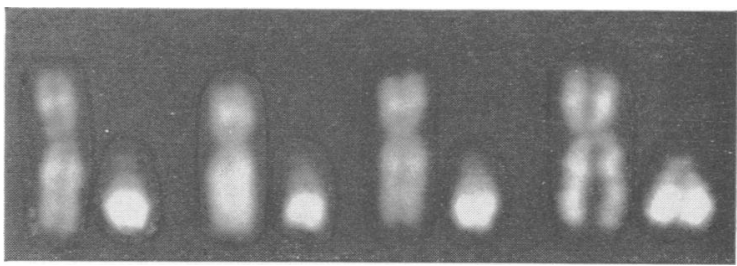

FIG. 3. $X$ and $Y$ chromosomes from four metaphases from the patient, showing the characteristic fluorescence patterns.

\section{Clinical Considerations}

The major manifestations of the present patient are listed in Table I, and compared to other cases in the literature which have been variously discussed under such titles as: 'true agonadism' (Overzier and Linden, 1956), 'pseudohermaphroditism with multiple congenital anomalies' (Schoen

\footnotetext{
* For a $46, X Y$ constitution.
} 
CHARACTERISTICS OF PRESENT CASE AND PREVIOUSLY REPORTEL

\begin{tabular}{|c|c|c|c|}
\hline & Present Patients & Emson and Buckwold (1965) & Dewhurst et al (1963) \\
\hline$\overline{\text { Age (yr) }}$ & 19 & 11 & 17 \\
\hline$\overline{\text { Body habitus; height }}$ & Eunuchoid; $155 \mathrm{~cm}$ & $145 \mathrm{~cm}$ & Eunuchoid; $169 \mathrm{~cm}$ \\
\hline Breast development & Absent & Absent & Minimal \\
\hline $\begin{array}{r}\text { Extragenital } \\
\text { anomalies }\end{array}$ & $\begin{array}{l}\text { High, arched palate; bilateral } \\
\text { ptosis; mongolian upper lids, etc } \\
\text { (see text) }\end{array}$ & None; full scale IQ 97, 94 & $\begin{array}{l}\text { No gross anomalies; nipples widely } \\
\text { spaced }\end{array}$ \\
\hline Family history & $\begin{array}{l}\text { Unremarkable; two normal brothers; } \\
\text { no consanguinity }\end{array}$ & $\begin{array}{l}\text { Six sisters: normal; three brothers: } \\
\text { normal }\end{array}$ & $\begin{array}{l}\text { Only child; mother } 35 \mathrm{yr} \text { at birth of } \\
\text { the patient }\end{array}$ \\
\hline Sex of rearing & Female & Male & Female \\
\hline External genitalia & $\begin{array}{l}\text { Female: absent vagina; normal } \\
\text { clitoris; infantile labia }\end{array}$ & $\begin{array}{l}\text { Ambiguous ; ? absent vagina; ? slightly } \\
\text { enlarged clitoris; two lateral folds } \\
\text { resembling labia majora; no scrotum; } \\
\text { single perineal urethral opening } \\
2.5 \mathrm{~cm} \text { deep posterior urethral } \\
\text { outpouching }\end{array}$ & $\begin{array}{l}\text { Female; absent vagina; minute blind } \\
\text { pit in region of introitus; normal } \\
\text { clitoris; labia majora: } \\
\text { underdeveloped; labia minora: } \\
\text { fused }\end{array}$ \\
\hline $\begin{array}{l}\text { Internal genitalia } \\
\text { Gross examination }\end{array}$ & $\begin{array}{l}\text { No uterus: no gonadal tissue; small } \\
\text { structure on lateral pelvic walls }\end{array}$ & $\begin{array}{l}\text { No genital organs; no testes or ovaries; } \\
\text { 'two ovoid bodies' in region of } \\
\text { internal ring }\end{array}$ & $\begin{array}{l}\text { No uterus; two tiny remnants on } \\
\text { lateral walls; no gonadal tissue }\end{array}$ \\
\hline $\begin{array}{l}\text { Histological } \\
\text { examination }\end{array}$ & Rudimentary fallopian tubes & $\begin{array}{l}\text { 'Tubular structures of } 3 \text { types'; } \\
\text { immature fallopian tubes; } \\
\text { epididymis-like 'paraovarian } \\
\text { tubules' }\end{array}$ & $\begin{array}{l}\text { 'Small tubular structure resembling } \\
\text { uterine horn; tubules of Wolffian } \\
\text { duct' }\end{array}$ \\
\hline $\mathrm{X}$-chromatin & Negative & Negative & Negative \\
\hline Chromosomes & $46, X Y$ & $46, \mathrm{XY}$ & $46, X Y$ \\
\hline
\end{tabular}

et al, 1955), 'an XY female with absent gonads and vestigial pelvic organs' (Dewhurst, Paine, and Blank, 1963), 'agonadism' (Emson and Buckwold, 1965), and 'gonadal dysgenesis with androgenic manifestations' (Chaptal et al, 1958). Only those cases with some evidence for a male sex chromosome constitution (eg, absence of Barr bodies) are included; only three of the reported cases, including the present one, had a chromosome analysis.

It is evident from the data in Table $I$ that the present case and those previously reported are similar in many respects. All were X-chromatin negative and, where studied, had an XY constitution. All, except the prepubertal cases (Schoen et al, 1955; Chaptal et al, 1958; Emson and Buckwold, 1965), had eunuchoidal body measurements; except for one case (Dewhurst et al, 1963) all lacked breast development. The sex of rearing was female in all except the case of Emson and Buckwold (1965). Although the present patient and the case of Schoen et al (1955) showed several minor extragenital anomalies, as a rule there seem to be no consistent major abnormalities. The vagina was absent in all cases; in three cases (Schoen et al, 1955; Overzier and Linden, 1956; Emson and Buckwold, 1965) an enlarged clitoris and variable degrees of labioscrotal fusion were described. In two cases (Overzier and Linden, 1956; Philipp, 1956) a urogenital sinus was present; in another two (Chaptal et al, 1958; Emson and Buckwold, 1965) a small vaginal outpouching from the urethra was noted. The internal genital anomalies are similar in all cases. True internal genital structures such as uterus, fallopian tubes, or gonads are lacking; instead, small structures are located on the lateral pelvic walls and are variably described as 'ovoid bodies', 'gonads', or 'hypoplastic tubes'. Histologically, these structures are tubular and resemble in some instances the epididymis, and in others, the epoophoron, and in our case, the fallopian tube.

In his book 'Intersexuality', Overzier (1961) included his sib cases and the cases of Schoen et al (1955), Philipp (1956), and of Chaptal et al (1958) as examples of the same clinical entity. His postulation of a probable sex chromosome abnormality as aetiology of the syndrome has not been confirmed. We have included these and other cases in Table I, and feel that they all represent a distinct nosologic 
CASES OF PRESUMED XY GONADAL AGENESIS SYNDROME

\begin{tabular}{|c|c|c|c|}
\hline Chaptal et al (1958) & $\begin{array}{l}\text { Overzier and Linden (1956); } \\
\text { Overzier (1961) }\end{array}$ & Philipp (1956) & Schoen et al (1955) \\
\hline $10 \frac{1}{2}$ & 15 and 12 & 18 & $11 \frac{1}{2}$; bone age $-8 \mathrm{yr}$ \\
\hline $132 \mathrm{~cm}$ & $\begin{array}{l}\text { Stocky habitus; } 161 \text { and } 135 \mathrm{~cm}, \\
\text { respectively }\end{array}$ & Eunuchoid; $169 \mathrm{~cm}$ & $135 \mathrm{~cm}$ (15th centile for age) \\
\hline Absent & Absent & Absent & Absent \\
\hline None & None & Turricephaly & $\begin{array}{l}\text { IQ } 85-95 \text {; alternating esotropia; } \\
\text { spina bifida occulta L5; S1; } \\
\text { turribrachycephaly; deafness } \\
\text { right ear }\end{array}$ \\
\hline 3 sibs: healthy & $\begin{array}{l}\text { Positive: } 2 \text { affected sisters; } \\
2 \text { normal sisters }\end{array}$ & 4 older healthy sibs & Negative \\
\hline Female & Female & Female & Female \\
\hline $\begin{array}{l}\text { Female; doubtful sex at birth; no } \\
\text { vagina; small clitoris-like phallic } \\
\text { tubercle with prepuce; small } \\
\text { outpouching from urethra; } \\
\text { labioscrotal fusion; no scrotum } \\
\text { or labia }\end{array}$ & $\begin{array}{l}\text { Female; absent vagina; enlarged } \\
\text { phallic organ with small } \\
\text { opening at its base; } \\
\text { urogenital sinus; high } \\
\text { perineum with median raphe }\end{array}$ & $\begin{array}{l}\text { Female; no vagina; hypoplastic } \\
\text { clitoris; hypoplastic labia; } \\
\text { short urogenital sinus }\end{array}$ & $\begin{array}{l}\text { Female; absent vagina; clitoris- } \\
\text { like phallic tubercle with } \\
\text { prepuce; no scrotum or labia; } \\
\text { male-type urethra }\end{array}$ \\
\hline $\begin{array}{l}\text { No uterus; no gonads; Right- } \\
\text { possibly hypoplastic tube }\end{array}$ & $\begin{array}{l}\text { No uterus; no gonads; tiny } \\
\text { structure on lateral pelvic wall }\end{array}$ & No uterus; no gonads; no tubes & $\begin{array}{l}\text { No uterus; no gonadal tissue; } \\
\text { no fallopian tubes }\end{array}$ \\
\hline $\begin{array}{l}\text { Right-epididymis and } \\
\text { epoophoron-like tubules }\end{array}$ & $\begin{array}{l}\text { Primitive tube with } \\
\text { mesonephric-type tubules }\end{array}$ & Not described & $\begin{array}{l}\text { Left-epoophoron; Right- } \\
\text { epididymis-like tubules }\end{array}$ \\
\hline Negative & Negative & Negative & $\begin{array}{l}\text { '5\% X-chromatin positive' } \\
\text { (probably X-chromatin } \\
\text { negative) }\end{array}$ \\
\hline Not studied & Not studied & Not studied & Not studied \\
\hline
\end{tabular}

entity. We would like to call it 'the $\mathrm{XY}$ gonadal agenesis syndrome'.

This syndrome is clearly different from the feminizing testis syndrome (FTS) and from the Swyer syndrome; the latter two conditions are also characterized by a non-mosaic $46, \mathrm{XY}$ chromosome constitution and by female external genitalia (Table II).

The XY gonadal agenesis syndrome is also different from the vaginal atresia syndrome (the socalled Mayer-Rokitansky-Küster syndrome [Bryan, Nigro, and Counsellor, 1949; Hauser and Schreiner, 1961]), in which a $46, \mathrm{XX}$ sex chromosome constitution is combined with normal ovarian development and maturation of female secondary sex characteristics, and frequently with major anomalies (eg, of kidneys, the cardiovascular system, etc).

\section{Developmental Considerations}

We are impressed with the possibility that this is a (malformation) syndrome on the basis of the associated anomalies that have been observed: skull defects (turricephaly, turribrachycephaly), vertebral anomalies, low posterior hair-line, high, arched palate, ptosis with epicanthic (mongolian) folds, suggestive heterochromia iridis, nystagmus, alternating esotropia, possible dermatoglyphic abnormalities, and borderline intelligence $(97,94$ in one case; 85-95 in another). Also, the unique genital and gonadal findings suggest an unusual pathogenesis. The external genitalia may have a nearly normal female appearance (save for absence of the vagina); more commonly they show hypoplasia of labia, some degree of labioscrotal fusion, a small clitoris-like phallus without urethra but with dorsal prepuce, a small perineal urethral opening, and rarely a small 'pseudovaginal' urethral outpouching (Chaptal et al, 1958; Emson and Buchwold, 1965). Thus, in some cases, the external genital picture does suggest the intrauterine effect of testosterone; however, in no case was a testis found.

In human males, normal inhibition of Müllerian duct differentiation and stimulation of Wolffian ducts towards male gonaductal development occurs under the influence of a fetal testis. On the other hand, Müllerian duct development and regression of the Wolffian ducts, does not require ovaries; 
TABLE II

CHARACTERISTICS OF THE XY GONADAL AGENESIS SYNDROME COMPARED WITH THE FEMINIZING TESTIS SYNDROME AND SWYER SYNDROME

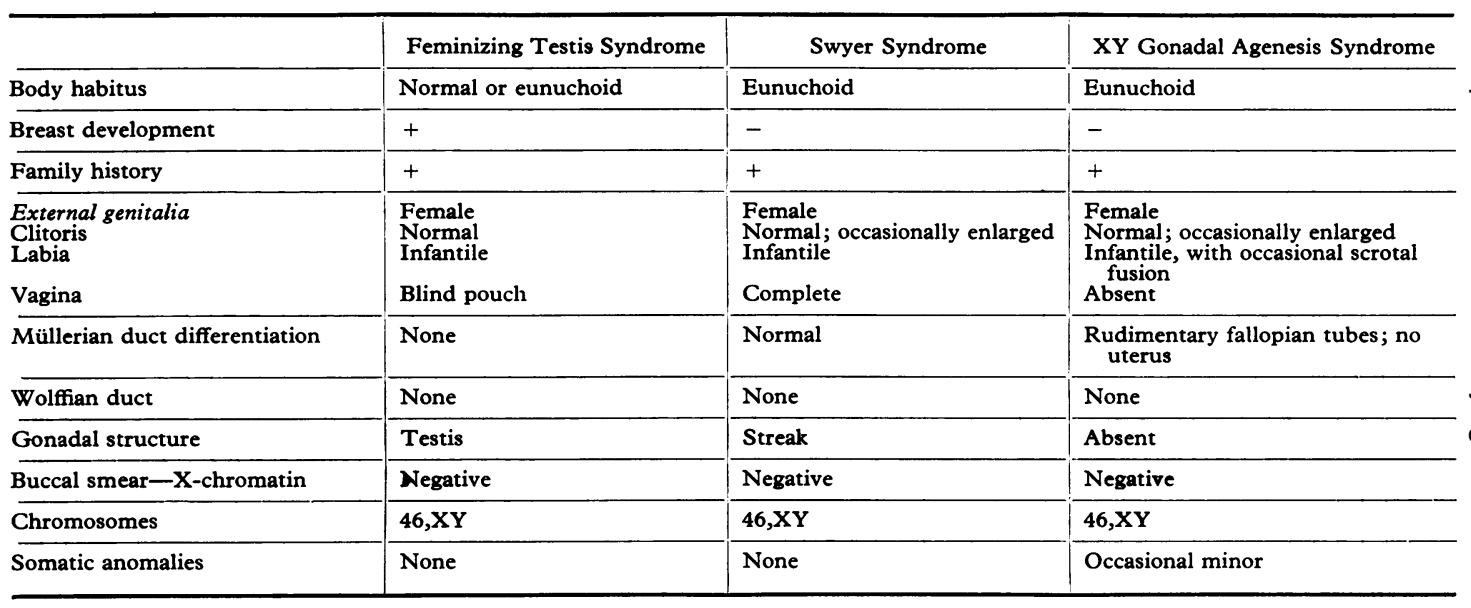

indeed, it may occur in the absence of any gonadal tissue. As demonstrated by Jost (1947) in rabbits, and other investigators working with rats (Wells and Fralick, 1951) and mice (Raynaud and Frilley, 1947), the fetal testis is required for regression of the Müllerian ducts; early testicular dysgenesis leads to the development of apparently normal female internal genitalia without the simultaneous differentiation of Wolffian duct structures. Also, in the rabbit, Jost noted that if castration of the male was delayed beyond a certain stage, the Müllerian ducts continued to undergo involution as usual. Thus, there is a limited period of time during which involution of the Müllerian ducts is determined, and once this has occurred, the effect is irreversible. The Wolffian duct structures, however, require the testis for continued survival as well as differentiation.

In the present patient and in the other reported cases, no gonads could be found to account for the internal genital findings. Perhaps, as in Jost's experiments (1947), the fetal testis was functional for a sufficient time to induce the Müllerian duct inhibition, but not long enough to maintain Wolffian duct development. A short activity of the fetal testis would also account for the partially virilized external genitalia. Another explanation for the genital/gonadal anomalies of this syndrome is a complete primary deficiency of all gonaductal anlagen with severe concomitant deficiency of the fetal testis which functioned either not at all or only long enough to effect a minimal degree of masculinization of the external genitalia.

\section{Genetic Considerations}

The study of the inheritance of various genes which alter or reverse sexual development is difficult because the affected individuals are sterile.

Numerous intersex conditions in $46, \mathrm{XY}$ an $\vec{\varphi}$ $46, \mathrm{XX}$ individuals are known; most of these occue as sporadic cases. Some are 'familial disorders' these can be divided into two groups. First, a clas probably representing the homozygous state of autosome recessive mutations (eg, the adrenogenital syndromes, pseudovaginal perineoscrotal hypospadias [PPSH], the uterine hernia syndrome [UHS], and probably the Swyer syndrome); and secondly, a class representing either male-limited autosomal dominant or $\mathrm{X}$-linked recessive inheritance (eg the FTS, the incomplete FTS, Reifenstein syndrome, and some cases of the Swyer syndrome). Some of the conditions in the first group affect both sexes (ie, the adrenogenital syndrome), some are limited in expression to one sex (usually the male sex, eg, the UHS and PPSH). So far, no proven case of an X-linked locus affecting sex development in man is known; however, work on the X-linked Tfm mutation in the mouse (and similar conditions in the rat and cow) suggests that the FTS in man may also be an X-linked recessive of mutation (Ohno, Tettenborn, and Dofuku, 1971). However, linkage studies in the FTS have not shown linkage with any known X-linked locus. Sporadic cases of these disorders may represent new mutations, chance isolated cases, or different genetic entities altogether. 
The seven cases which represent the present 'gonadal agenesis syndrome' are sporadic except for the two sibs described by Overzier and Linden (1956). We consider the gonadal agenesis syndrome to be a genetic disorder; however, at the present time no conclusions can be drawn concerning the mode of inheritance of this condition.

We would like to thank John L. Claude, MD, Oconomowoc, Wisconsin, for referring the patient, and Dr E. Therman, and Professor K. Patau for the chromosome fluorescence studies.

\section{REFERENCES}

Bryan, A. L., Nigro, J. A., and Counseller, V. S. (1949). One hundred cases of congenital absence of the vagina. Surgery, Gynecology and Obstetrics, 88, 79-86.

Chaptal, J., Jean, R., Pages, P., Campo, C., Bonnet, H., and Duntze, F. (1958). Sur un cas de dysgénésie gonadique avec manifestations androgéniques. Archives Françaises de Pédiatrie, 15, 613622 .

Dewhurst, C. J., Paine, C. G., and Blank, C. E. (1963). An XY female with absent gonads and vestigial pelvic organs. Fournal of
Obstetrics and Gynaecology of the British Commonwealth, 70, 675680 .

Emson, H. E. and Buckwold, A. E. (1965). Agonadism. Canadian Medical Association fournal, 93, 1080-1083.

Hauser, G. A. and Schreiner, W. E. (1961). Das Mayer-RokitanskyKüster Syndrom. Schweizerische medizinische Wochenschrift, 91, 381-384.

Jost, A. (1947). Recherches sur la différenciation sexuelle de l'embryon de lapin. II. Action des androgénes synthése sur l'histogénése génitale. Archives d'Anatomie Microscopique et de Morphologie Expérimentale, 36, 242-270.

Ohno, S., Tettenborn, U., and Dofuku, R. (1971). Molecular biology of sex differentiation. Hereditas, Genetiskt Arkiv, 69, 107-124.

Overzier, C. (1961). Echter Agonadismus. In Intersexualität, pp. 348-352, ed. by C. Overzier. Georg Thieme, Stuttgart.

Overzier, C. and Linden, H. (1956). Echter Agonadismus (Anorchismus) bei Geschwistern. Gynaecologia, 142, 215-233.

Philipp, E. (1956). Die Fehlbildungen der Keimdrüse. Deutsche medizinische Wochenschrift, 81, 1298-1302.

Raynaud, A. and Frilley, M. (1947). Destruction des glandes génitales de l'embryon de souris, par une irradiation au moyen des rayons X, a l'age de treize jours. Annales d'Endocrinologie, 8, 400-419.

Schoen, E. J., King, A. L., Baritell, A. LaM., and Knigge, W. F. (1955). Pseudohermaphroditism with multiple congenital anomalies. Report of a case. Pediatrics, 16, 363-371.

Wells, L. J. and Fralick, R. (1951). Production of androgen by the testes of fetal rats. American fournal of Anatomy, 89, 63-107. 